\title{
Migrant Domestic Workers: Good Workers, Poor Slaves, New Connections
}

Abstract: In public debates support for migrants' rights has generally taken two approaches: the migrant as 'Good Worker' or the migrant as 'Poor Slave'. This paper will constructively critique these approaches by considering the case the case of a UK campaign demanding a specific visa for migrant domestic workers and how they drew on the Good Worker/Poor Slave. It describes the campaign's initial focus on domestic workers as workers and how this required demanding special rights as migrant workers on the basis of the specific conditions in the private household, at the same time as calling for paid domestic work to be recognised as a job like any other. The campaign was initially successful, but the right to change employer was withdrawn in 2012. The revived campaign was this time situated within the debates about 'modern slavery' and the paper will consider some of the ways in which the UK government has responded to this. It will argue for the importance of not reifying the difference between 'migrant' and 'citizen', thereby recognising connections between national and non-national workers, and also between commodified and non-commodified reproductive labour. Given the low level of public debate at the moment this may not be possible for campaigners but academics must continue in attempts to raise the level of public debate.

Everyone is talking about immigration. The impacts of migration on the social, the economic and the political are perceived as multifarious and profoundly disruptive. In fact, the proportion of people that move internationally, approximately 3 per cent of the world's population, has long been stable but the meaning, significance and constitution of mobility have changed. The story told today is one of unparalleled movement and huge demographic shifts. While the summer of 2015 saw an unexpected change in attitudes of certain segments of the European public manifest in a wave of support for 'refugees' if not for 'migrants', mobility continues to be presented as a problem or a crisis, certainly not in any way as a solution to the problems and crises faced by the people who move.

Those NGOs and public figures who position themselves as 'pro-migrant' have generally made two types of argument: the migrant is a contributor who does the jobs that 'natives' don't want to or do not have the skills to do - the migrant as 'Good Worker'; or the migrant is exploited and victimised, has been duped, into situations that can resemble 'modern slavery' - the migrant as 'Poor Slave'. This paper will constructively critique these approaches by considering the case of migrants who work as domestic workers. Migrant domestic workers and their supporters have drawn on ideas of both the 'good worker' and 'poor slave' in many countries of the world to advance their calls for recognition and rights. This paper will examine the case of a UK campaign demanding a specific visa for migrant domestic workers and the strengths and risks of these two frames. It will begin by describing the campaign for migrant domestic workers in the UK to have their right to change employer recognised, and this campaign's focus on domestic workers as workers. Rights recognised as a result were later withdrawn in 2012 , and the campaign reignited, but this time very much framed by the language of 'modern slavery' and the paper will consider some of the ways in which the UK government has responded to this. It will argue for the importance of not reifying the difference between 'migrant' and 'citizen', thereby recognising connections between national and non-national workers, and also between commodified and non-commodified reproductive labour. 
Given the low level of public debate at the moment this may not be possible for campaigners but academics must continue in attempts to raise the level of public debate.

\section{Domestic labour, mobility and visas}

There is nothing new about people moving to work in the households of others to do housework and care labour (Fauve-Chamoux 2004; Hoerder 2002). Life cycle service, when young people moved to other households to undertake agricultural and home based work as a transition to setting up their own family was a part of life for centuries (Cooper 2004). Daughters-in-law moving into their husband's family home, and children moving to live and work in wealthy relatives' households have been common practices in many regions of the world for centuries. In the face of this, one must be wary of making claims about a shift in the scale of mobility (rather than migration) to work in private households. However, there have been important shifts in patterns of movement and in who moves. In many parts of Europe domestic workers used to come from rural areas to work in cities, but mobility for domestic labour today is often likely to be across greater distances and workers come from both within and outside the European Union (EU). This is within a context of significant changes in global relations and inequalities, technology and communication (Hoerder 2002). There have also been changes to the relation between geographical mobility and labour relations, and the ways in which states regulate mobility and regulate domestic labour. Taken together these these mean that the ways in which household labour is subordinated in capitalist societies have multiplied. The burdens of regulation fall more significantly on some than on others. Mrs Wang was deported from just outside Oxford because she had entered on a visitor's visa to spend time with her sister, brother-in-law and two-and-a-half-year-old niece. She had told officials that she was looking after the toddler, and in the eyes of the immigration officer charged with her case, this meant she was working as an unpaid nanny and therefore in breach of her conditions of stay (Oxford Mail $10^{\text {th }}$ December 2008). Would a wealthy white American uncle have counted as an unpaid nanny?

In EU states migrant ${ }^{1}$ labour in private households tends to be concentrated in live-in work, which is often, but not necessarily, associated with caring for children, the disabled and the elderly. Where these people come from depends on many factors, including colonial history, geography, and networks. Fiona Williams has examined how national regimes of care, migration and employment have led to the employment of migrant care workers across the EU. National variations between these regimes and the different ways they intersect explain the differences in the rate, extent and nature of migrant employment and whether they are employed in private households or in institutions, but these are 'converging variations' within a transnational political economy of care (Williams 2012, 2014). Williams' analysis is of care work, of which domestic labour may be, but is not necessarily, a part. However, the regimes of care, migration and employment, shaped and shaping the gendered division of labour, are also critical factors in understanding the position of migrant domestic workers more generally.

\section{Domestic Work: a job like any other?}

\footnotetext{
${ }^{1}$ I am using the term 'migrant' broadly here to include EU nationals not residing in their state of citizenship. This usage is not uncontested.
} 
Unlike many EU states the UK has not ever had a programme to admit people working as domestic workers in UK based households. Until 2008 the UK did have arrangements governing the entry of au pairs, but the au pair visa was issued for people living 'as part of the family' and was explicitly not a work visa (Cox 2015). Thus the many non-UK citizens who are working in private households cooking, cleaning and caring are on a range of visas, including dependent, visitor, and student as well as permanent residents, EU nationals and asylum seekers (Cangiano et al. 2009). Some will be able to do this work without breaching their conditions of stay, others will be working illegally, and for many the situation is ambivalent (Anderson and Ruhs 2010). For many years the only means of entering the UK with the immigration status of domestic worker has been to accompany an employing family entering the UK. From 1977 such arrangements were governed by a special concession that required workers to stay with the employer with whom they entered. These employers were generally wealthy people coming on holiday or for business. They included UK citizens returning from a period abroad but generally the concession was designed for non-citizens living and working with non-UK citizen families. It was not a response to demand from British based employers but rather a requirement of a system designed to facilitate the mobility of the wealthy. As Lord Reay, speaking for the government, said in 1990:

Looking at our national interest, if wealthy investors, skilled workers and others with the potential to benefit our economy were unable to be accompanied by their domestic staff they might not come here at all but take their money and skills to other countries only too keen to welcome them.

Hansard col. $105228^{\text {th }}$ November 1990. House of Lords Debate on Overseas Domestic Workers.

The fact that the entry of domestic workers was an immigration concession meant it fell outside the immigration rules that governed migrant workers more generally. In practice it gave rise to a wide range of visas: some workers would be given a visitor's visa with an 'employment prohibited' stamp, others had permission to enter to work for their employer, with the name of the employer written on their visa, others were given permission to enter as family members (Anderson 2000). What these visas had in common was that the domestic worker did not have permission to work, and if she left the employer that she had entered with she lost her immigration status and became an illegal resident. This gave considerable power to employers and in effect meant workers could be abused with impunity. There was widespread exploitation and physical abuse, workers left employers, and by the mid-1980s London hosted a population of illegalised domestic workers in the several thousands.

These workers became politically active from the late 1980s and, supported by the campaigning group Kalayaan, organised around a call to be recognised as workers with a focus on the right to change employer. The right to change employer would enable them to escape dangerous situations and acknowledge their status as independent workers. This claim was lent particular rhetorical force by the fact that most visas were issued to domestic workers accompanying families from the Middle East, and while the campaign attempted to avoid the stereotype of the evil Arab public interest often tapped into powerful ideas about uncivilised Others. These foreign families, in stark contrast to the British host families of au pairs for example, were depicted by the media as cruel and exploitative with an ever present threat of physical and sexual abuse. 
The campaign and self-organising of domestic workers, facilitated by the Transport and General Workers Union (TGWU, now UNITE the union), meant that in 1998 the newly elected Labour government agreed to incorporate domestic workers accompanying their employers into the immigration rules. Most of those who had been illegalised were given permission to stay, though the discretionary nature of the original visa meant that some found it easier than others (Anderson, 2000). For new entrants, a visa was introduced that gave workers the right to change to work for another household. They were eligible to access employment tribunals and join trades unions and subject to employment protections including the minimum wage as long as they were not treated as part of the family. In terms of entry provisions however, domestic workers were still dependent on their employers, and the new visa continued to be for the benefit of employers entering or returning to the UK.

The personal consequences of the success of the domestic worker campaign should not be underestimated. Over four thousand illegalised domestic workers, mainly from the Philippines, India and Indonesia, but also from Nigeria, Burkina Faso, Cameroon and other African states, won their status and those who entered under the new visa regime were able to take some control over their lives were they to find themselves abused. Yet while domestic workers were successful in their call for rights as workers, demanding that their job be treated like any other, this was also a call for exceptional treatment as migrants. In the UK as in many other countries, visas for employment typically require sponsorship and restrict all but the most elite holders to work for a particular employer. Though their labour is commodified, migrant workers do not have the same freedom to contract as citizens (Fudge and Strauss 2014). In the discussions around the visa changes in 1997 this was reflected in the fact that a proposal to incorporate domestic labour into the general provisions covering migrant workers was rejected. If it were treated in the same way as any other job done by a non-citizen, this would mean withholding the right to change employer, the central campaign demand. So their claim for fundamental rights as workers was a claim for rights as British workers.

In order to make this claim for exceptional rights as migrants, i.e. to be incorporated into the immigration rules, but not incorporated into the mainstream regulation governing immigration for employment, the campaign highlighted the specificities of domestic work. Yet the call for rights as British workers was not couched in terms of equal rights with British workers working in private households. Indeed, while there has been considerable media attention given to the plight of domestic workers entering the UK with their employers, there has been surprisingly little attention paid to issues facing paid domestic workers more generally in the UK. Domestic work in the UK, as in many other states, is not fully integrated into the labour market nor is it offered equal labour protection. All employment relations are social, but domestic labour in private households is a relation it is particularly difficult to stabilise and depersonalise through an employment contract (Anderson 2000). Domestic workers are not covered by the weekly forty-eight hour restriction set out in the Working Time Regulations for the limitation of working hours, and the Health and Safety Executive (HSE) has no remit to inspect private households. Workers are exempt from the minimum wage if they are living-in and treated as part of the family. Until 2015 there was no requirement that employers pay into pensions for carers and cleaners working in private homes. These limitations are compounded by a delicate equilibrium of transgression that means that the widespread informality and illegality in the sector is not considered a problem. It is immigration status that has so far proved 
the campaigning and organising flashpoint, rather than contractual and employment issues for household workers more generally.

Thus in terms of its emphasis on domestic workers as workers the campaign had to negotiate the fact that low waged migrant workers are typically tied to their employers, and the problem of accommodating domestic work in private households within employment contracts, yet at the same time demand that domestic work should be treated as a job like any other. This was managed by arguing that tying domestic workers to employers was particularly egregious because of the personalised rather than the contractual nature of their working relationship and the lack of oversight of employment conditions. Thus the right won by domestic workers was not a general right to change employer but a right to change employer in the case of abuse. This kind of caveat is not typical - it is not generally the case that one's right to leave an employer is restricted to cases of abuse by a line manager. However, this caveat made it possible to for domestic workers to change employer and be recognised as workers without incorporation into the rules governing migrant workers. In this way too it was possible to ring fence domestic work as a special case and not risk it setting a precedent - because it was not a job like any other.

\section{Domestic Workers as 'modern day slaves'}

The visa and the right to change employer began to come under pressure with attempts to limit 'low skilled' migration. Faced by growing concern about immigration following EU Enlargement in 2004 and unexpectedly high numbers of EU migrants, in 2006 the Labour Government had announced that it was introducing a new points based system (PBS) for managing migration The PBS was designed to restrict entry to the 'brightest and the best', people identified as having the skills to benefit to the British economy. It suspended low skilled migration routes, as employer demand for this kind of work could, it was argued, be met by intra-EU migration. Unsurprisingly, given the gendered nature of skill (Jenkins 2004), the PBS has had very different implications for women than for men. In 2009 two thirds of applicants were male, and over three quarters of Tier 2 skilled applicants were male (Murray, 2011).

Domestic labour was regarded as low skilled and it was argued that if there was a shortage, this could be met by EU migrants. However, pressure from campaigning groups and trades unions was exerted on the Labour Government to keep the domestic worker scheme and its proposed abolition was postponed for two years awaiting a review of anti-trafficking strategy. During these two years a general election saw a new Conservative/Liberal Democrat Coalition, and, in 2011 this government reinvigorated the proposals. The Conservatives had made a commitment to limit 'net migration', or the difference between the number of 'migrants' entering and leaving the UK. The figure set as sustainable was tens of thousands, a significant drop from 252,000 which was the figure when the Coalition came into power in 2010. It was evident from the outset that achieving a number under 100,000 was going to prove extremely difficult (Migration Observatory 2011). The Government had very limited control over migrants from the European Economic Area (EEA), and none at all over UK nationals. Non-EEA workers, so-called Third Country Nationals (TCNs) who did not have human rights claims were one of the few groups whose numbers could be brought down using immigration policy 
levers. At that time there were approximately 15,000-17,000 domestic worker visas issued annually ${ }^{2}$. Most (approximately 94\%) did not renew their visa after a year and presumably left the country, and rates of settlement were under 5\% (Lalani 2011), suggesting both that the visa was working and that migrant domestic workers were not contributing to large scale migration to the UK. Nevertheless the government introduced tough new rules to limit numbers of new visas.

Since April 2012 domestic workers accompanying their employers have only been eligible for a sixmonth non-renewable visa and they cannot legally change employer. Government ministers did not dispute that employment in private households could be abusive, but: 'We do not necessarily believe that a right to change employer whatever the reason is the only way to provide protection' (Currell 2012: 12). The Home Office argued rather disingenuously that the principle protection for migrant domestic workers was now to be refusal of entry. 'The biggest protection for these workers will be delivered by limiting access to the UK through these routes' (Home Office 2012). Those who were abused under the six month tied visa would have recourse to protections via anti-trafficking measures and a promised Modern Slavery Bill. Kalayaan had always kept statistics of abuse reported when new clients registered with them. They found that in 2012/13, the year after the introduction of the tied visa, $62 \%$ of those registered received no salary as compared to $14 \%$ the previous year; $100 \%$ had no day off, compared to $46 \%$ the previous year, and $96 \%$ were not allowed out of the house, compared to $44 \%$ the previous year.

The 2012 changes to the visa occurred in a context where the impact of migration on labour markets and communities was construed as strongly negative. For over a decade the Labour Government had argued that economic migrants were good for growth and the economy (Flynn 2003), and this approach had come under attack even before the financial crash. The infamous prediction that not having transitional measures to control free movement in an enlarged EU would only result in some additional 15,000 people entering the country proved a gross underestimate. This was seized on by the then Conservative opposition and the media. The ensuing debate saw the apparent contradiction of the left arguing for the value of migration on the basis of efficiency and productivity and the right arguing against it on the basis of protecting the rights of the white working class.

The Good Worker argument became ever more difficult to make following the 2008 crash and growing demands for 'British jobs for British workers' ${ }^{3}$. However, while the space for arguing that domestic workers were contributors had contracted, there was considerably more room for antislavery arguments. By 2012 there had been over a decade of campaigning against trafficking by a wide range of actors. International, national and local newspapers and media, churches, women's groups, local authorities, human rights and migrants' organisations not to mention states and international organisations had, from the early 2000s onwards, found common cause in stamping out trafficking and modern day slavery (O'Connell Davidson 2006). The UK government was an early signatory to the 2001 UN protocol on Trafficking in Persons Especially Women and Children and had introduced a set of offences of traffic in prostitution in the 2002 Nationality, Immigration and

\footnotetext{
${ }^{2}$ This does not necessarily mean 12,000 new entrants as it includes an unknown number of multiple entries in a single year.

${ }^{3}$ UK Labour Prime Minister Gordon Brown's phrase attracted some criticism, but the justificatory logic that labour migration controls protect national labour markets and citizens should be given priority access to jobs is normally viewed as unremarkable.
} 
Asylum Act. This was in keeping with that period of anti-trafficking activism very much focussed on trafficking as prostitution (Outshoorn 2005).

Concerted efforts by campaigners and activists at a national and global level including the International Labour Organisation, shifted the ground towards an understanding of trafficking as including trafficking for the purposes of forced labour outside of prostitution (ILO 2005). This move contributed to the rise of the language of 'modern slavery' and meant that labour rights and migrants' rights groups could find common cause with states in denouncing exploitation and abuse of migrants as victims of trafficking or modern day slavery. In these debates domestic work effectively bridged sex trafficking and trafficking for forced labour/modern slavery. The victims of 'domestic slavery' drew from the same group of poorer women who are often migrants (rural to urban or international). Like prostitution/sex work, paid domestic work is caught between the public and the private and whether commodification is the source of the problem or offers a solution is subject to considerable debate (O'Connell Davidson 2006, Outshoorn 2005). The overlaps were such that radical feminists pursuing an anti-prostitution agenda could support the expansion of antitrafficking activity to domestic labour because it is a sector that is dominated by women and girls, and integrally related with the reproduction of gender relations. Labour activists and sex workers rights feminists could also support this expansion because it is a sector where many of the problems spring from its deregulation and the low status given to the work.

Kalayaan took advantage of this space. In the earlier campaign the rhetoric of slavery had indeed been deployed, but now it had far greater public resonance. The campaign called for a reinstatement of the previous visa regime and claimed that the tied visa represented 'Slavery by another name' (Kalayaan 2014). The charge of slavery was specifically linked to the tying of domestic workers to their employers: 'In tying them to their employers we are fuelling slavery rather than fighting it' (Kalayaan 2014). Situating the new campaign in this way effectively accused the UK Government of hypocrisy. Ministers had made considerable play of their support for anti-slavery not least through heavily publicised promotion of a Modern Slavery Bill. Kalayaan's claims were supported by people who were outside the usual suspects of trades unions and migrants rights activists and found a much broader base than had been possible in the 1980s. For example, among those calling for a reinstatement of the right to change employers was the Centre for Social Justice (CSJ), a Conservative think tank established by the Conservative Work and Pensions Minister, lain Duncan-Smith.

However, while everyone can agree that trafficking and modern slavery is wrong, what is meant by these terms, and what the source of the problem is, are subject to considerable disagreement. This campaign illustrates that consensus about the evils of slavery can hide very different analyses of the role of immigration controls in situations of 'modern slavery'. Domestic workers and supporters argued that immigration controls contributed to constructing vulnerability by tying workers to employers. In contrast, the Home Office proposed to stop abuse by domestic workers, and abusive employers by border checks. Those abusing domestic workers would not be allowed entry (and neither would their workers). In the rare case that an abuser should slip through the net the domestic worker could have recourse to anti-trafficking protections. 
This position goes beyond the claim that sponsorship arrangements enforced by immigration controls are compatible with free labour, and present immigration controls and enforcement as a means of protecting migrants from slavery, and as points of intervention where individual abusers and criminal gangs can be identified and brought to justice. Indeed the idea that people must be saved from slave traders by border controls and enforcement has become widespread. In 2015 the response of many European governments to large numbers of people attempting to cross the Mediterranean in rickety boats was to claim that these people (many of whom had fled civil war and violence in Syria, Afghanistan, Iraq and Eritrea) were victims of 'latter day slave merchants' ${ }^{4}$. At one stage some EU governments were even proposing to use force and bomb boats to prevent them from leaving Libya, - claiming thereby to be saving people from the slave trade but in practice confining them to Libya, riven by warring factions, corruption, violence, and racist hostility. UK Home Office Minister Teresa May advocated those rescued be taken to 'safe landing sites in North Africa' before being returned, while Northern League leader Matteo Salvini suggested taking rescued people to disused oil platforms off the Libyan coast abandoned by the Italian energy firm ENI in order not to 'disturb' Italians: 'Help them, rescue them and take care of them, but don't let them land here's.

It is clear from these responses that one problem with using immigration controls and border enforcement as a point of intervention is that the same body that is charged with protecting vulnerable migrants from slavery is also charged with prevention of entry and illegalisation, and deporting or imprisoning those found to be in breach of immigration controls. The focus on identifying victims and villains ignores the role of the state in creating vulnerability and in handing over power to employers. In the case of domestic workers, the removal of a visa that gave rights to migrants as independent workers and the promise to help those most egregious cases while at the same time enforcing removals against people who have left abusive employers reveals a flaw at the heart of the system.

In its presentation of immigration enforcement as a process that is supportive of migrants' rights the UK Government emphasises the problem of barbaric foreign employers as key to vulnerability, drawing strongly on ideas of the Uncivilised Other which were latent in the first campaign, but now far more explicit. Home Secretary Theresa May professed herself concerned that 'the overseas domestic worker routes can at times result in the import of abusive employer/ employee relationships to the UK'. At the same time a more charitable interpretation is placed on British employers' non-recognition of workers' rights. The UK government declined to sign the ILO Convention on the Protection of Domestic Workers (Convention 189) depicting a very different type of British employer threatened by the expansion of rights to household workers:

we do not consider it appropriate, or practical, to extend criminal health and safety legislation, including inspections, to cover private households employing domestic workers. It would be difficult, for instance, to hold elderly individuals, who employ carers, to the same standards as large companies.

\footnotetext{
${ }^{4}$ http://frontex.europa.eu/feature-stories/people-smugglers-the-latter-day-slave-merchants-UArKn1

${ }^{5}$ Post on Salvini's facebook page cited in http://www.theguardian.com/world/2015/aug/23/italy-coastguard3000-migrants-rescued-one-day
} 
Statement by Ms Warwick, International Labour Conference Record of Proceedings 15 June $201125(\mathrm{rev}), \mathrm{p} 22$ ).

This reveals another problem with the slavery narrative: it relies for its political purchase on what are often very extreme cases, not the 'elderly individuals' unable to cope with the bureaucracy of labour rights. The government can realistically say that most cases are not cases of rape and extreme physical violence. More mundane abuses and indignities - not being given a bed, working excessive hours, being paid a pittance, or indeed not having a pension paid, are far more common, but difficult to characterise as 'modern slavery'. Using the same terminology of 'abuse' the government argues that most domestic workers leaving employers are not themselves abused, but are in fact 'abusing' the system. The Government claims that they are leaving employers, not because they were abused (i.e. for the right reason) but simply because they wanted to remain in the UK (the wrong reason).

These limitations were exposed in debates around the Modern Slavery Bill. Crossbench peer Lord Hylton tabled an amendment in the House of Lords (the UK Parliament's Upper Chamber) proposing to include in the Bill the reinstatement of the right of migrant domestic workers to change employers as a means of 'protection from slavery'. The government's response is worth quoting at length:

The only way that we will tackle this crime is to bring it out from the shadows and shine a light on the abuse and the abusers. This means that we have to find the victims and support them in their recovery. We will not be able to do that if those being abused are not encouraged to come forward. House of Lords Amendment 72 sadly works in the opposite direction. It allows someone who is on ODW visa to change employer without having to come forward to the authorities. Unfortunately this means that abusive employers will be protected from being exposed and the cycle of abuse will continue - a slave master will find a new victim to fulfil his or her needs and we will have no way of finding them.

Letter from Lord Bates, Parliamentary Under-Secretary to the Home Office, to Baroness Royall of Blaisdon, $13^{\text {th }}$ March 2015

According to this, people working for abusive employers are only encouraging abuse by leaving them, rather than trusting the authorities and reporting their problems. The rejection of the Lords' amendment effectively gave migrant domestic workers who are abused two options: either they come forward to the police or they stay with violent abusers. It put the onus on the workers to present themselves to the authorities, but these authorities have already stipulated that they must remain with their employers. In this version of fighting slavery recognising workers' rights is, bizarrely, not an anti-slavery measure.

\section{Immigration and domestic work: making connections}

The situation of domestic workers is clearly far more complex than is captured by the Good Worker or the Poor Slave, and it offers some useful insights into the contradictions inherent in managing labour migration. Firstly the contrast between the mobility of employing families and the constraints placed on domestic workers reveals how the entry of the wealthy continues to be actively courted by the government at the same time as ever more hurdles are put in the way of low waged migrants. 
A well-designed immigration policy facilitates the movement of the rich and obstructs the movement of the poor (Anderson 2013). The migration of the wealthy can entail the migration of their households including domestic workers, and this presents policymakers with a real tension. This is an illustration at a household level of Saskia Sassen's (2001) explication of the relation between the lives of global elites and demand for low waged labour.

\section{Making connections with workers}

One of the ways in which the mobility of the poor is restricted is through the discourse of 'skills'. Domestic labour is, in immigration terms, 'low skilled' work. It is tacit rather than codified knowledge, imagined as innate or acquired through disposition rather than formal training (Kofman 2007). Its quality is not measured by output but by the experience of the employer. It exemplifies many of the kinds of jobs created in service economies which demand 'soft skills'. These are often highly rhetorically valued, though this value is typically not recognised in financial recompense. This value is rarely reflected in immigration regimes that typically regard skills as being about formal training and wages. In domestic work, as in other service roles, employers will often much prefer a worker who has experience, or the right attitude, or is seen to be a certain kind of personality, over a worker who has qualifications, and formal training and wages can be inadequate as gauges of skill (Anderson and Ruhs 2010). Furthermore, the case of domestic workers exposes the problems with assuming that work designated as low skilled is easy and can be done by anyone. Low skilled labour is imagined as fungible, easily replaceable, and this is critical to the logic of immigration policy. It is, arguably, one of its ideological bases: to protect low skilled nationals from competition in the labour market, precisely because anyone can do those low skilled jobs. When the visa was abolished in 2012 the government repeated the claim that a six months visa is sufficient time for an employing family to find another worker who has EU citizenship as a replacement. But fungibility cannot be assumed: a person who is trusted, who understands how a household works, leaving aside caring relations with children and elderly people, cannot simply be swapped for another employee. Who does the work, matters.

The difficulties accommodating commodified domestic labour within immigration regulations reflect the difficulties in extending the employment contract to the private home. It is one of the defining feature of labour relations that they are distinct from family/household relations, hence the 1998 visa allowed that domestic workers who were treated as 'family workers' could still be denied workers' rights ${ }^{6}$. As the case of Mrs Wang reveals, what counts as work is contingent, gendered, classed and racialized. Moreover, traditional ideas of contract and employment relations as imagined by immigration laws - a single employer, prepared to guarantee work and take on responsibility for an employee for a set period of time - are increasingly removed from many people's experiences of their job even when they are not domestic workers. The fantasy of the labour market as depicted by immigration controls collides with many people's experiences of working. Europe has seen a growth in agency working, self-employment, interning and so on. So while domestic work in private households is often viewed as exceptional there multiple new forms of working relations, and the so-called standard employment contract should not be assumed to be

\footnotetext{
${ }^{6}$ What constitutes being treated as part of the family has been the subject of several legal cases. One case noted that an employing family did not display their worker's photograph in their home as evidence that they were not regarded as part of the family. This led to some consternation on the part of au pair agencies, who rely on this exemption to avoid minimum wage for au pairs.
} 
the norm. If we understand precarity, poor conditions and low wages as 'migrant work' then in practice a lot of the jobs on offer are, to paraphrase UK Prime Minister Gordon Brown 'Migrant jobs for British workers'.

The 'Good Worker' claim can make it difficult to explore these connections. It contains a strongly implicit contrast with the Poor or Lazy Worker, suggesting that enthusiasm for poor work is somehow a characteristic of certain nationalities with a good work ethic. It overlooks the fact that while the national labour market is marked in immigration policy and discourse as a space of privilege for citizens, it is in practice a disciplinary area for national workers, for whom work is not a right but a duty. Across the European Union multiple conditions are imposed on unemployed nationals include mandatory participation in employment-related programmes, job search interviews, and unpaid work placements (Anderson et al. 2014). Analysing the ways in which low waged labour markets produce demand for certain kinds of workers, required to tolerate insecurity and low wages, and examining the different ways in which potential workers are constrained, including through immigration restrictions and welfare benefit conditionality, can challenge assumptions of labour market competition between nationals and non-nationals.

\section{The connections of reproductive labour}

The market has emancipated some women from domestic and care labour, and done so without requiring a rebalancing of the gendered division of labour. Some women can work because they are able to replace their household and caring labour. However, the position of domestic worker is not new and nor is their poor treatment. Female domestic workers and slaves have for centuries rebelled against cruelties perpetrated by their mistresses. The arrangement of care and domestic labour in the private household is a powerful indication of the divisions between women across multiple axes and the story of male domination of women must be understood as overlaid by relations of race and class. In the history of property and citizenship women qua women have not been totally excluded, but differentially included, and mechanisms for women's differential in/exclusion were and are shaped by race, class, sexuality, whether they were deemed able in mind and body and of course citizen/subject/ immigration status (Anderson, 2013). For this reason it has often been seen to be politically important to unmake the connection between women and to highlight the differences, particularly those of race and class, between employer and worker, between wife and servant. In the face of sometimes horrendous physical and psychological abuses perpetrated by female employers on their workers, the subordination often required by female employers, and the reproduction of grotesque global inequalities in private households, not to mention the very real daily differences of interest, even the most sympathetically engaged employer and worker are unlikely to find more than ambivalent allegiances.

Yet however ambivalent there are allegiances. An historical perspective draws attention to the relations between migration/mobility for domestic work and migration/mobility as a 'wife' and to the ways in which the social reproductive labour of female employers has also been separated from that of the women that they employ. Indeed while the argument of the domestic worker campaign was that not allowing domestic workers to leave employers was condemning them to 'slavery' ${ }^{7}$ a more accurate analogy might be that they were being treated as wives, or as members of the family,

\footnotetext{
${ }^{7}$ I made this argument myself in a campaign booklet published by Anti-Slavery International called, regrettably, Britain's Secret Slaves
} 
who could not leave the family without an irrevocable change in status. The rhetoric of employers who claimed that domestic workers were part of the family was indeed interrogated and challenged, but this critique was not integrated into the challenge to domestic workers' immigration status precisely because they wanted to escape the status of being part of the family'. The reproductive labour of wives tends to be overlooked in European migration scholarship and while there have been many powerful campaigns protesting the injustices experienced by those on dependent visas the contribution and necessity of their reproductive labour is only recently being noted (Kofman 2012).

The relation is more complex than a collision, one woman commodifying her labour at another's expense. Employers are not necessarily wealthy, middle class and white. A single mother working as a care assistant may well find that a live in au pair is the only affordable childcare, particularly if she has more than one child. Domestic workers themselves can often employ live in carers to look after relatives in their countries of origin. The structuring power of the patriarchal family too often gets left out of the picture in the portrayal of the relation between women, and while acknowledging the importance of differences between female employer and worker, this should not obscure the usefulness of making connections between paid and unpaid domestic labour, between social devaluation and the creation and extraction of economic value.

This is particularly important given that across Europe, social expenditure cuts and public service retrenchment threaten the capacity of communities to care, at the same time as women are pushed into the low waged service sector with threats of welfare sanctions if they fail to demonstrate proper engagement with the labour market. Social reproduction is ever more devalued and subservient to the public world of work. Across the EU the promotion of women's labour market participation, alongside the pursuit of active labour market policies more generally, prioritise the benefits of full-time work for all adults, and individual responsibility to maintain an income through the labour market has become the principle under which (minimal) state welfare is provided.

\section{Conclusion}

The current European context makes attempts to counter hostility to migration through the 'Good Worker' and the 'Poor Slave' increasingly difficult to maintain. The Good Worker is a competitor with citizens for jobs, the Poor Slave must be prevented from entry, or removed for their own best interests. This is potentially compounded by the resurgence of the refugee/migrant dichotomy further limiting the political space available to those who are claiming rights as non-citizens but who are not 'refugees'. The history of the struggles of migrant domestic workers and their supporters suggests that one alternative to the Good Worker and the Poor Slave is to look for the connections between 'migrants' and 'citizens'. That is, to recognise differences between nationals and nonnationals at the same time as demonstrating structural links between the experiences and relations of both. Making these kinds of connections is particularly important in the context of a political debate which pits migrants against the unemployed at the same time as fanning hostility to both as the undeserving poor. This requires a sustained critique of free labour that the rhetoric of modern slavery actively discourages, but that equally is discouraged by claims that migrant workers do jobs that national workers reject because they are too low status or poorly paid. 
In practice many campaigners are well aware of the limitations of the Good Worker and the Poor Slave but have few options given the low level of public debate on immigration and its strong reliance on emotional responses. When having to respond to the emergencies of daily deportations and destitution the most effective tool currently available is to appeal to what the public will recognise. This makes it incumbent upon those of us who are not under these kinds of pressures to complicate public debate. We need to not reify difference between migrants and citizens, and to find ways to demonstrate the connections between migrants and citizens. The private household is an obvious, if challenging, place to start.

Anderson, B. 2000. Doing the dirty work? The global politics of domestic labour. London: Zed books Anderson, B. 2013 Us and Them? The dangerous politics of immigration controls. Oxford: Oxford University Press

Anderson, B. 2014. "Precarious Pasts, Precarious futures." In Migrants at Work, edited by C Costello and M Freedland 29-43 Oxford: Oxford University Press

Anderson, B., Shutes, I. \& Walker S. 2014 Report on the Rights and Obligations of Citizens and NonCitizens in Selected Countries available from http://beucitizen.eu/publications/report-on-the-rightsand-obligations-of-citizens-and-non-citizens-in-selected-countries/

Anderson, B. and Ruhs, M. 2010. "Migrant workers: who needs them? A framework for the analysis of shortages, immigration, and public policy". In Who needs migrant workers? labour shortages, immigration, and public policy, edited by M Ruhs and B Anderson, 15-52. Oxford: Oxford University Press

Anderson, B. and Ruhs, M. 2010 "The origins and functions of illegalilty in the migrant labour market" Population, Space and Place, 16(3): 195-211.

Cangiano, A., Shutes, I., Spencer, S. and Leeson, G. 2009. "Migrant Care Workers in Ageing Societies: Research Findings in the United Kingdom." Oxford: COMPAS

Centre for Social Justice 2013 "Establishing Britain as a world leader in the fight against modern slavery: Report of the Modern Slavery Bill Evidence Review." London: CSJ

Cooper, S. M. 2004. From Family Member to Employee: "Aspects of Continuity and Discontinuity in English domestic Service 1600-2000." In: Domestic Service and the formation of European Identity: Understanding the Globalization of Domestic Work, 16th-21st Centuries, edited by A FauveChamoux, A., 277-296. Bern: Peter Lang.

Cox, R.. ed. 2015. Au Pairs' Lives in global Context: sisters or Servants? London: Palgrave

Currell, J. 2012. Response to the OSCE Report on Human Trafficking. London. Organised and Financial Crime Unit, HMSO

Fauve-Chamoux, A. ed. 2004. Domestic Service and the formation of European Identity: Understanding the Globalization of Domestic Work, 16th-21st Centuries. Bern: Peter Lang. Flynn, D. 2003. "Tough as Old Boots? Asylum, immigration and the paradox of New Labour policy." London: Joint Council for the Welfare of Immigrants.

Fudge, J. and Strauss, K. "Migrants, Unfree Labour, and the Legal Construction of Domestic Servitude: Migrant Domestic workers in the UK." In Migrants at Work: Immigration \& Vulnerability in Labour Law, edited by Cathryn Costello and Mark Freedland, Page 160-179. Oxford: Oxford University Press 
Hoerder, D. 2002. Cultures in contact: world migrations in the second millennium. Durham: Duke University Press

Home Office 2012. Immigration (Employment-related settlement, Overseas Domestic Workers, Tier 5 of the Points Based System and Visitors). Statement of Intent: 29 February 2012, London, HMSO. Honig, B. 2003. Democracy and the Foreigner. Princeton: Princeton University Press International Labour Organisation (ILO). 2005. "A global alliance against forced labour. A global report under the follow up to the ILO declaration of fundamental principles and rights at work." Geneva: ILO

Jenkins, S. 2004. Gender, Place and the Labour Market. Ashgate: Aldershot

Kalayaan, 2014. "Slavery by another name: the tied migrant domestic worker visa" last modified May 7, 2015, accessed May 20, 2015, http://www.kalayaan.org.uk/wp-content/uploads/slavery-bya-new-name-briefing.pdf

Kofman, E. 2007. 'The knowledge economy, gender and stratified migrations' Studies in Social Justice 1(2): 122-135

Kofman, E. 2012. "Rethinking Care through Social Reproduction: Articulating circuits of migration." Social Politics 19 (1): 142-162

Lalani, M. 2011. Ending the Abuse: policies that work to protect migrant domestic workers, London: Kalayaan

Migration Observatory, 2011. Accessed May 20,

2015 http://migrationobservatory.ox.ac.uk/commentary/target-government-policies-are-not-trackreducing-net-migration-tens-thousands-2015

Murray, S. 2011. Britain's Points Based Migration System, London: CentreForum

O'Connell Davidson, J. 2006. "Will the Real Sex Slave please stand up?" Feminist Review no. 83 Sexual Moralities: 4-22

Outshoorn, J. 2005. "The political debates on trafficking and prostitution of women" Social Politics 12 (1): 141-155

Sassen, S. 2001. The Global City. New York, London, Tokyo. Princeton: Princeton University Press Van Walsum, S. 2008. The Family and the Nation. Dutch family migration policies in the context of changing family norms. Newcastle-Upon-Tyne: Cambridge Scholars Publishing

Williams, F. 2012. "Converging variations in migrant care work in Europe." Journal of European Social Policy 22(4): 363-376

Williams, F. 2014. "Making Connections Across the Transnational Political Economy of Care." In Migration and Care Labour: Theory, Policy and Politics, edited by B Anderson and I Shutes, London: Routledge 